\title{
Supply Side Studies That Affect Educated Unemployed in Central Java, Indonesia
}

\author{
Muhit Nur Hidayah ${ }^{1} \&$ Lukman Hakim ${ }^{2}$ \\ ${ }^{1}$ Faculty of Economic and Busines, Magister of Economic Development, Sebelas Maret Maret University, Indonesia \\ ${ }^{2}$ Faculty of Economic and Busines, Study Program of Economic Development, Sebelas Maret Maret University, Indonesia \\ Email: muhitnh@gmail.com
}

http://dx.doi.org/10.18415/ijmmu.v6i1.540

\begin{abstract}
The long term demographic transition impacts on the explosion of productive age population number and even the demographic trend shows an increasing productive age population growth pattern. There is a worry that the productive age populations not be absorbed in job opportunity will be unemployed. Productive age unemployment will impact on the high educated unemployment rate. This research would analyze demographic and social factors underlying educated unemployment in Central Java in 2018 from supply side only. The data used was raw data on the result of National Labor Force Survey (SAKERNAS) conducted by BPS-Statistics of Central Java Province on February with 3375 respondents being the sample. The methods employed were descriptive and binary logistic regression analyses. The result of research showed that age, family member number, sex, and relationship to household head, marital status, residence area, and on-the-job training variables simultaneously affected the predisposition of educated work force to be unemployed. Meanwhile, partially family member number and residence area variables did not affect an individual's predisposition to be educated unemployed.
\end{abstract}

Keywords: Educated Unemployment; National Labor Force Survey; Central Java

\section{Introduction}

In this last decade, Indonesia has encountered demographic transition phenomenon leading to the explosion of productive age population in long term. The structure of Indonesian population's age changes in which the proportion of productive-age population (15-64 years) is much higher than that of under-15 population. It leads to the decreased dependency ratio. Indonesian dependency ratio was 50.5 in 2010 and decreased to 48.6 in 2015. It is predicted that this figure will decreased to 47.7 in 2020 . It means that 100 productive-age populations assume 48 unproductive populations (under-15 and above-64 years). The phenomenon of lowered dependency ratio occurring continuously will reach the lowest point during 2020-2030. Thus, a window of opportunity is opened to be utilized to get economic benefit called demographic bonus. Otherwise, if Indonesia cannot utilize this opportunity, it will be instead led to the disaster due to high unemployment rate. A large quantity of labor force offer in the future will improve per capita income when productive job opportunity is available. 
On the other hand, the advantage of demographic bonus, Indonesia is now dealing with serious manpower problem, the higher unemployment rate. Unemployment problem in developing countries such as Indonesia is the complicated and serious one. The increased economic growth is not automatically followed with significant decrease in unemployment rate. Unemployment is a condition of an individual who has not gotten job yet while the individual belongs to labor force (Sukirno, 2008). Manpower problem is one point to which attention is largely paid by Central Java Province government. Considering the Regional Medium-Term Development Plan (Indonesian: Rencana Pembangunan Jangka Menengah Daerah or RPJMD) of Central Java in 2013-2018, one out of seven regional development missions (goals) is "to realize the just society welfare, to overcome poverty and unemployment". Central Government Province's goal in manpower area is the lowered unemployment rate, by means of lowering the open unemployment rate. Indicator of unemployment is percentage Open Unemployment Rate (OUR). The targeted OUR in 2018 is 4.20 as included in RPJMD of Central Java Province. Unemployment issue in Central Java currently needs serious attention recalling the unemployment related to poverty and high unemployment rate resulting in negative consequence to the community, for example, criminality. During 2013-2018, Central Java Province's economy grows continuously. In 2017, the growth rate was 5.27 and it increased to 5.41 in 2018. However, this economic growth is not automatically followed by the growth of job opportunity. It indicates that high economic growth alone cannot solve unemployment problem. This condition can be seen from the poor condition of manpower in Central Java, for example, no significant reduction in the open unemployment rate in the last six years.

Considering the recent manpower condition in Central Java in 2018, the BPS-Statistics of Central Java Province reported that the labor force number was 18.23 million people per February 2018, increasing by 224 thousands points compared with that on August 2017. Components composing Labor force are employed and unemployed populations. The employed (working) population consisted of 17.46 millions people per February 2018, increasing by 276 millions people compared with that in last year. Meanwhile, the unemployment rate was 0.77 million people, decreasing by 53 thousands points compared with that in last year. In Central Java, Open Unemployment Rate is 4.57 percents in 2017, decreasing by 0.06 point compared with that in 2016. The presence of long term demographic transition leads to the explosion of productive-age population number and even the demographic trend shows an increasing productive age population growth pattern. There is a worry that the productive age populations not be absorbed in job opportunity will be unemployed. Productive age unemployment will impact on the high educated unemployment rate. The educated unemployment rate will worryingly increase over years as the number of Senior High School or equivalent and College graduates also increases continuously. However not all of those graduates can be accommodated in work realm. As a result, it will encourage the increase in educated unemployment rate in Indonesia. Sanisah (December 2010) citing United Nations Development Programme (UNDP)'s report saw the unemployment pattern in developing countries including Indonesia as a unique phenomenon in which unemployment rate is found higher among those having high education. Such condition occurs as well in Central Java.

The group contributing mostly to the open unemployment rate is unemployed group with Senior High School education. More than a half of open unemployed persons have Senior High School or higher education, 54.93 percents. It indicates that job opportunity has not been able yet to accommodate unemployed persons with high education (Senior High School or higher). Their struggle for acquiring education ends up with the difficulty in getting job. On the other hand, they are potential resources that should be accommodated to spur Indonesian economic development rate. Allen's (2016) study suggested that a third of unemployed youth should wait for entering into job market, particularly formal job market, for a year. 


\section{Literature Review}

Labor supply is the ratio of wage level to labor number offered. In short term, a labor offer analysis assumes that there is no change in either labor population number or skill level (Santoso, 2010). Manpower Principal Law No.13 of 2003, in its Article 1 of General Stipulation of Chapter I, defines labor as every individual who is able to do job in order to produce product or service, to meet both his own or community's need.Statistics of Indonesia defines unemployed as those not working or seeking job, for example, those having not worked yet and attempting to get job. It also includes those who have worked but quit or are terminated by a company for some reasons and currently are attempting to get job. Educated unemployed labor in developing countries generally consists of youth and educated group. This unemployed group consists of largely labors newly completing education and waiting for the job as intended.

Moeis (1992) conducted a research entitled "Educated Unemployed Labor in Indonesia: The Application of Search Theory. Moeis studied factors affecting the educated labors' length of time being unemployed in rural and urban areas. This study found that the estimation using OLS and Probit suggested that Senior High School graduates seek for job longer than colleges graduates, and they have higher probability of being unemployed than Junior High School graduates.Setyadi (2008) conducted a study entitled "Analysis on Educated Unemployed Labor with Search Theory in Job Market in Central Java using a multiple linear regression method. The result of research showed that education and age (2439 year age) affects the job seeking probability and the job seeking duration. Sex variable affects job seeking probability while status in household affect the job seeking duration. The higher the education or the younger the age, the higher is the job seeking probability and the longer is the job seeking duration.

Wahyuni (2009) conducted a research entitled Analysis on Educated Unemployed Labor in West Sumatera. This study aimed to find out social-economic variables such as marital status, age level, education level, region, and sex on educated unemployed labor in West Sumatera. This study employed logistic regression method to analyze the data of National Social Economic Survey (Susenas) in 2007. The result of study showed that education, marital status, and sex affect the educated unemployed labor positively and significantly in West Sumatera, and age level affects the educated unemployed labor negatively and significantly. Meanwhile, region variable affects the educated unemployed labor positively but insignificantly in West Sumatera.Bairagya (2015) conducted a study on social-economic factors affecting educated unemployment in India. This study used data resulting from NSSO (National Sample Survey Organization)'s survey in 2011-2012 with probit analysis. Age, squared age, household member number, religion, social group (ST, SC, OBC), sex, status in job market, vocational training, residence, technical education, and industrialization status were used as the variable of research. The result of study showed that all of variables but social group (ST, SC) were significant.

Saleh (2016) conducted a study on the factors affecting educated unemployment in West Sumatera Province, with the limitation to offering aspect only. This study used data of National Labor force Survey in 2014-2015 with logistic regression analysis. From the result of research, it could be seen that sex, age, marital status, and skill affect the educated labor force's opportunity of being unemployed. Pratomo (2017) conducted a research entitled "Educated Unemployment Phenomenon in Indonesia. This research employed data of National Labor force Survey (Sakernas) in 2016 aiming to see the factors affecting an individual with high education to be unemployed in Indonesia (educated unemployed). Some aspects putatively affected educated unemployment in Indonesia: labor demand and offer factors, such as labor absorption in industrial and service sector, minimum wage level, and such individual characteristics as age, marital status, and economic background of family. The analysis method employed was logit multinomial analysis to see the characteristics of educated unemployed. The result of research showed that there are some other significant variables: family head, sex, age, marital status, urban area, job experience, and residence area, while insignificant variables are training, education major, and migration. 


\section{Research Method}

Data source employed in this study derived from Statistics of Central Java Province. The data was collected through National Labor Force Survey (Sakernas) conducted by Statistics of Central Java Province. Sakernas is a survey designed specifically to collect data that can represent the general condition of Indonesian manpower. This survey referred to an international concept, ILO Concept Approach, thereby comparable to other countries. Manpower theory approach in Sakernas has used Standard Labor Force Concept as included in International Conference of Labor Statisticians (ICLS) 13 and ICLS 19 since 1984.This research was conducted using secondary data analysis processed from raw data of National Labor Force Survey conducted by BPS-Statistics of Central Java Province in 2018. The data used in this study included data of households distributed in 35 regencies/cities in Central Java Province, Indonesia. The number of sample used is about 1,580 census blocks in both urban and rural areas, from each of which 10 households were taken. The sample in this research consisted of 3374 respondents.

Two analysis methods were employed in this research: descriptive and inferential analyses. (1) Descriptive analysis is a simple analysis explaining data using chart and table. In this case, descriptive analysis would provide general description on unemployment in Central Java, Indonesia. Descriptive analysis can also be used as a supporting instrument to sharpen further analysis. The unemployment in Central Java was described in tables and charts. (2) Logistic Regression analysis is used to explain the relationship between response variable in the form of binary dichotomy data and explanatory variable in the form of interval or categorical-scale data. Dichotomy/binary variable is the one having only two categories: the one representing successful event $(\mathrm{Y}=1)$ and another one representing failed event $(\mathrm{Y}=$ 0 ). In addition to because response variable is categorical data, logistic regression analysis is used because the explanatory variable employed in this study also used categorical data. Explanatory variable will not be able to fulfill homoscedasticity assumption; therefore, the analysis used was logistic regression analysis.

The model used in this analysis concerned the factors affecting an individual to be educated unemployed, expressed as follows:

$\mathrm{Y}=\mathrm{f}$ (Age, HHmembers, Gender, HeadOfHH, MaritalStatus, Residence, Training)

From the research model, it could be found the predictor of opportunity of being educated unemployed in a multiple logistic regression as follows:

$$
\begin{gathered}
\hat{g}(x)=\hat{\beta}_{0}+\hat{\beta}_{1} \text { Age }+\hat{\beta}_{2} \text { HHmembers }+\hat{\beta}_{3} \text { Gender }+\hat{\beta}_{4} \text { HeadofHH }+\hat{\beta}_{5} \text { MaritalStatus } \\
+\hat{\beta}_{6} \text { Residence }+\hat{\beta}_{7} \text { Training }
\end{gathered}
$$

\section{Results and Discussion}

\section{Descriptive Analysis on Characteristics}

Central Java Province consists of 35 regencies/cities. Open Unemployment Level of several regencies can be seen in Figure 1. BPS-Statistics of Central Java Province (2017) reported that the condition occurring on 2017, Open Unemployment Rate is 4.57 percents. Tegal City is the city with the highest level of unemployment, 8,19 percents. While the district of Semarang is the district with the lowest open unemployment rate, 1,78 percents. BPS-Statistics of Central Java Province (2018) reported that the condition occurring on February 2018, about 127.07 million people work (are employed) while 6.87 millions people are unemployed. 
Figure 1: Open Unemployment Level of several regencies in Central Java, Indonesia in 2017

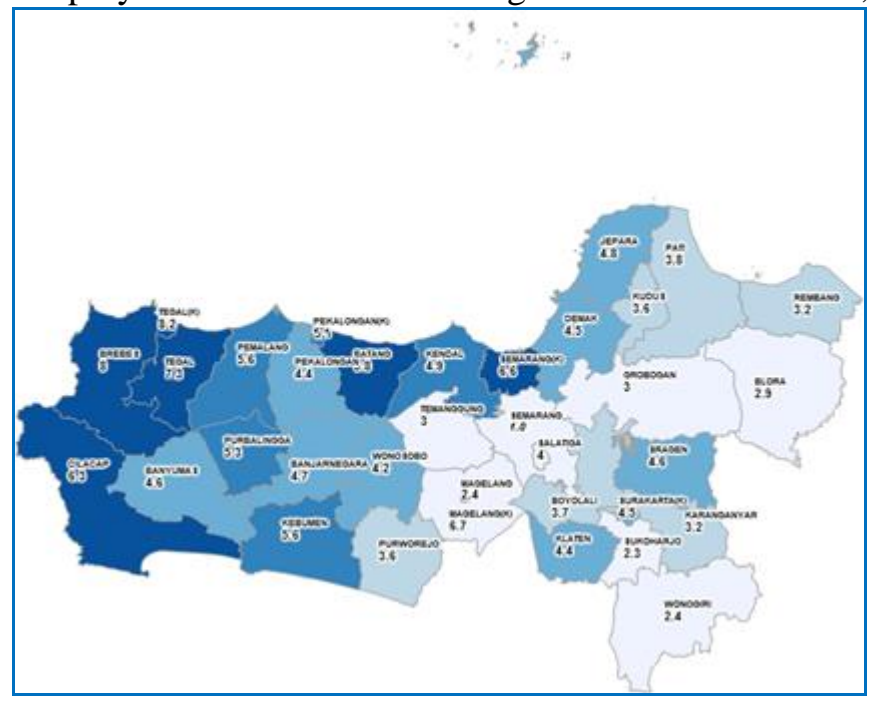

Table 1: Proportion of Educated Labor Force by Education in Central Java in 2018

\begin{tabular}{|l|l|l|l|l|l|l|}
\hline \multirow{2}{*}{ Education } & \multicolumn{2}{l}{$\begin{array}{l}\text { Educated } \\
\text { Workers }\end{array}$} & \multicolumn{2}{l|}{$\begin{array}{l}\text { Educated } \\
\text { Unemployed }\end{array}$} & \multicolumn{2}{l|}{ Total } \\
\cline { 2 - 8 } & $\mathrm{n}$ & $\%$ & $\mathrm{n}$ & $\%$ & $\mathrm{n}$ & $\%$ \\
\hline Senior High School or Equivalent & 1702 & $\begin{array}{l}71,6 \\
9\end{array}$ & 738 & $\begin{array}{l}76,3 \\
2\end{array}$ & 2440 & $\begin{array}{l}50,6 \\
1\end{array}$ \\
\hline College & 672 & $\begin{array}{l}28,3 \\
1\end{array}$ & 229 & $\begin{array}{l}23,6 \\
8\end{array}$ & 901 & $\begin{array}{l}49,3 \\
9\end{array}$ \\
\hline Total & 2374 & $\begin{array}{l}100, \\
00\end{array}$ & 967 & $\begin{array}{l}100, \\
00\end{array}$ & 3341 & $\begin{array}{l}100, \\
00\end{array}$ \\
\hline
\end{tabular}

Source: Labor Force Survey of 2018 (processed)

Educated labor force in Central Java consists of Senior High School or equivalent graduates (50.61\%) and college graduates (49.39\%). Most (71.69\%) of educated workers were graduated from Senior High School or equivalent, while the rest $(28.31 \%)$ were graduated from college or university. Meanwhile, the educated unemployed consisted of $76.32 \%$ graduated from Senior High School or equivalent and $23.68 \%$ from college or university.

Table 2 : Proportion of Educated Labor Force by Sex in Central Java in 2018

\begin{tabular}{|l|l|l|l|l|l|l|}
\hline \multirow{2}{*}{ Sex } & \multicolumn{2}{l|}{$\begin{array}{l}\text { Educated } \\
\text { Workers }\end{array}$} & \multicolumn{2}{l|}{$\begin{array}{l}\text { Educated } \\
\text { Unemployed }\end{array}$} & \multicolumn{2}{l|}{ Total } \\
\cline { 2 - 7 } & $\mathrm{n}$ & $\%$ & $\mathrm{n}$ & $\mathrm{n}$ & $\%$ & $\mathrm{n}$ \\
\hline Male & 1413 & 59,52 & 278 & 28,75 & 1619 & 50,61 \\
\hline Female & 961 & 40,48 & 689 & 71,25 & 1650 & 49,39 \\
\hline Total & 2374 & 100,00 & 967 & 100,00 & 3269 & 100,00 \\
\hline \multicolumn{6}{|c|}{ Source: Labor Force Survey of 2018 (processed) }
\end{tabular}


Educated labor force consisted of women (50.61\%) and men (49.39\%). Educated unemployment is dominated by female (71.25\%) and male (28.75\%). It is in line with an assumption that women have no obligation to work, so that educated female unemployment dominates more.

\section{Regression Analysis}

Logistic regression model for educated workers and educated unemployment in Central Java in the form of logit is expressed as follows:

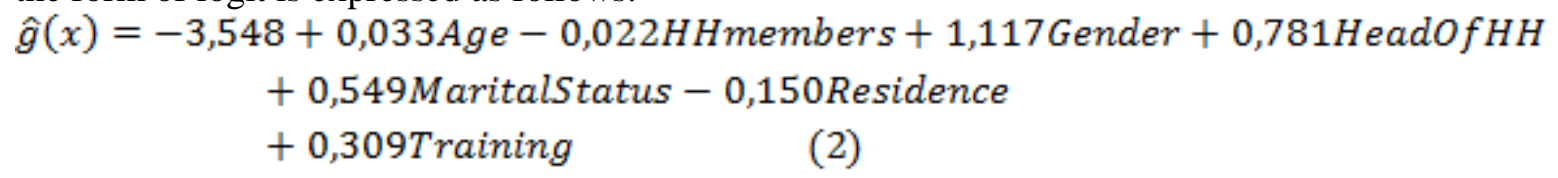

Meanwhile, the hypothesis testing on logistic regression coefficient using Wald test as presented in table 3 shows that the logistic regression coefficient is statistically significant at error level of 5\%.

Table 3: Result of Estimated Coefficient for Educated Worker and Educated Unemployment Complete Model, Wald Test Value, Significance, and Odd Ratio Value

\begin{tabular}{|l|l|l|l|l|}
\hline Variable Name & $B$ & Wald & Sig. & $\begin{array}{l}\text { Exp(B)/ } \\
\text { Odds Ratio }\end{array}$ \\
\hline Age & 0,033 & 61,838 & 0,000 & 1,033 \\
\hline House Hold Members & $-0,022$ & 0,664 & $0,415^{*}$ & 0,979 \\
\hline Gender & 1,117 & 122,073 & 0,000 & 3,054 \\
\hline Head of House Hold & 0,781 & 33,822 & 0,000 & 2,184 \\
\hline Marital Status & 0,549 & 23,363 & 0,000 & 1,732 \\
\hline Residence & $-0,150$ & 2,472 & $0,116^{*}$ & 0,861 \\
\hline Training & 0,309 & 11,723 & 0,001 & 1,362 \\
\hline constant & $-3,548$ & 162,839 & 0,000 & 0,029 \\
\hline
\end{tabular}

Considering the result of regression, the following conclusions can be drawn:

Age affects positively an individual's opportunity of being educated unemployment. The older the age, the greater is an individual's opportunity of being educated unemployed. As he is getting older, an individual will enter into work realm more difficultly. Odds ratio value of 1.033 can be defined as the older educated labor force's predisposition to be educated unemployed of 1.033 times higher than the younger one's. It is because the older the age of an individual, the more difficult is the process of adapting to work realm. In addition, there are age limitation in formal job market and reduced productivity as age increases.Sex affects positively an individual's opportunity of being educated unemployed. It means that female has higher opportunity of being educated unemployed. It is in line with an assumption that women have no obligation to earn living. Odds ratio value of 3.054 means that the women's predisposition to have an opportunity of being educated unemployed is 3.054 times higher than the women's.

The relationship to household head affects positively an individual's opportunity of being open unemployed. An individual in household with non-household head status has no obligation to work. People still assume that it is household head that obligatorily earns living. The odds ratio value of 2.184 means that the non-household head's predisposition to have an opportunity of being educated unemployed is 2.184 times higher than household head. Marital status affects positively an individual's opportunity of being educated unemployed, in which a single (not-married) individual has higher opportunity of being educated unemployed. It is because a not-married individual has not had family 
dependent yet, so that he has no obligation to work. Meanwhile, a married individual has had family dependent they should fund, so that whatever the job is available will be taken to support his family's life. The odds ratio value of 1.732 means that the women's predisposition to have an opportunity of educated unemployed was 1.732 times higher than the men's.

Job training affected positively an individual's opportunity of being educated unemployed. It is consistent with the hypothesis proposed. The positive effect of job training on educated unemployed can be interpreted that acquiring job training in Central Java will not guarantee that an individual will get a job. In this case, it occurs likely because of the reduced demand for skilled and educated labor. The odds Ratio value of -3.548 means that the educated labor force's predisposition to have an opportunity of being educated unemployed is 3.548 times than the unskilled one's.

\section{Conclusions and Suggestions}

From the result of research, it can be seen that age, sex, relation of household head, marital status and job training correlate significantly to the educated labor force's predisposition to be educated unemployed. Meanwhile, the effect of respective variables is explained as follows:

1. The older educated labor force's predisposition to be educated unemployed is higher than the younger one's.

2. The number of family members does not affect significantly the educated labor force's predisposition to be educated unemployed, meaning that an individual with either smaller or larger number of household members have equal predisposition to be educated unemployed.

3. Female educated labor force's predisposition to be educated unemployed is higher than the male one's.

4. A household head's predisposition to be educated unemployed is smaller than a non- household head.

5. A married individual's predisposition to be educated unemployed is lower than the not-married one's.

6. Residence area does not affect the uneducated labor force's predisposition to be educated unemployed.

Job training affects positively the educated labor force's predisposition to be unemployed. It is because educated unemployment tends to be dominated by older populations with not-married status, women, non-household head, and skilled ones, meaning that they have not been urged yet with economic need, so that they still have option to take or not to take a job. From the phenomenon above, regional development should be conducted immediately, particularly in disadvantaged and remote area as the priority of development. Not only large industry but also small industry should be developed, in which the qualification of small-scale industry to admit workers should not be as complicated as that of largescale industry, so that older workers, female workers, and other unemployed groups expectedly will be absorbed in work realm. The simplification of license should be conducted as well because too many licensing affairs constrain the investment recently, including Foreign Investment, Domestic Investment, and people investment (either individual or group). All of these should be accomplished to stimulate the people to create new job opportunity and investment.

\section{References}

Allen, E. R. (2016). Analysis of Trends and Challengers in The Indonesian Labor Market. Asian Development Bank $(A D B)$. 
Alphonsa, M. (1994). Educated Unemployment in Kerala. Kochi, India: University of Science and Technology.

Badan Pusat Statistik. (2007). Statistik Pengangguran 2001-2006. Jakarta: Badan Pusat Statistik.

Badan Pusat Statistik. (2012). Analisis Statistik Sosial (Bonus Demografi dan Pertumbuhan Ekonomi). Jakarta: Badan Pusat Statistik.

Badan Pusat Statistik. (2018, Mei). Berita Resmi Statistik Keadaan Ketenagakerjaan Indonesia Februari 2018.

Badan Pusat Statistik. (2018). Pedoman Pencacah Survei Angkatan Kerja Nasional. Jakarta: Badan Pusat Statistik.

Badan Pusat Statistik Provinsi Jawa Tengah. (2018). Keadaan Angkatan Kerja Agustus 2017. Semarang: Badan Pusat Statistik Provinsi Jawa Tengah.

Bairagya, I. (2015). Socio-Economic Detrminants of Educated Unemployment in India. Working Paper 343.

Becker, G. (1993). Human Capital : A theoretical and Empirical Analysis, with Special Reference to Education (3rd ed). Chicago: The University of Chicago Press.

Borjas, G. J. (2013). Labor Economics Sixth Edition. New York, America: McGraw-Hill.

Cendrawati, N. K. (2000). Analisis Pengangguran di Indonesia Berdasarkan Data Sakerti 1993. Jakarta, Depok: Universitas Indonesia.

Dornbusch, R., Fischer, S., \& Startz, R. (2004). Makro Ekonomi. Jakarta: PT Media Global Edukasi.

Elfindri, \& Bachtiar, N. (2004). Ekonomi Ketenagakerjaan. Padang: Andalas University Press.

Hartina, D. (2009). Faktor-Faktor Yang Mempengaruhi Pengangguran Terselubung di Pedesaan Jawa Tengah Analisis Data Sakernas 2007. Jurnal Kependudukan Indonesia, Vol. IV, No.1, 15-32.

Indriantoro, N., \& Supomo, B. (1999). Metodologi Penelitian dan Bisnis. Yogyakarta: BPFE Yogyakarta.

Latan, H. (2014). Aplikasi Analisis Data Statistik Untuk Ilmu Sosial Sains dengan IBM SPSS. Bandung: Alfabeta.

Mada, M., \& Ashar, K. (2015). Analisis Variabel Yang Mempengaruhi Jumlah Pengangguran Terdidik di Indonesia. Jurnal Ilmu Ekonomi dan Pembangunan, 15, 50-76.

Maryati, S. (2015). Dinamika Pengangguran Terdidik: Tantangan Menuju Bonus Demografi Di Indonesia. Journal of Economic and Economic Education Vol.3 No.2, 124 - 136.

Miller, R. L., \& Meiners, R. E. (2000). Teori Ekonomi Mikro Intermediate Edisi Ketiga. Jakarta: PT. RajaGrafindo Persada.

Moeis, J. P. (1992). Pengangguran Tenaga Kerja Terdidik di Indonesia : Penerapan Search Theory. Ekonomi dan Keuangan Indonesia Vol.40, No. 2, 107-134.

Osman, M. M., \& all, e. (2015). Unemployment Issues and Problems in Kinta, Manjung and Kuala Kangsar, Perak, Malaysia. Procedia - Social and Behavioral Sciences, 168, 389399.

Pasay, N. H., \& Indrayanti, R. (2012, Januari). Pengangguran, Lama Mencari Kerja, dan Reservation Wage Tenaga Kerja Terdidik. Jurnal Ekonomi dan Pembangunan Indonesia, 12 No.2, 116-135.

Pratomo, D. S. (2017). Fenomena Pengangguran Terdidik di Indonesia. Sustainable Competitive Advantage-7 (SCA-7) FEB Unsoed, 642-648.

Putri, R. F. (2015, 2). Analisis Pengaruh Inflasi, Pertumbuhan Ekonomi dan Upah Terhadap Pengangguran Terdidik. Economics Development Analysis Journal, 4, 175-181.

Sadono, S. (1993). Pengantar Teori Ekonomi Mikro (4th ed.). Jakarta: FE UI. 
Saleh, D. A. (2016). Analisis Faktor-Faktor Yang Mempengaruhi Pengangguran Terdidik di Provinsi Sumatera Barat. Padang: Universitas Andalas.

Sanisah, S. (Desember 2010). Pendidikan Tinggi dan Pengangguran Terbuka: Suatu Dilema. Lentera Pendidikan Vol: 13,No 2, hal 147-159.

Sari, N. R. (2016, Juni). Pengaruh Variabel Ekonomi Makro Terhadap Pengangguran Terdidik di Jawa Timur 2010-2014. Jurnal Ekonomi Pembangunan, 14, 71-84.

Setyadi, D. (2008). Analisis Pengangguran Tenaga Kerja Terdidik dengan Pendekatan Search Theory pada Pasar Kerja di Jawa Tengah. http://lib.ui.ac.id diakses tanggal 14 Oktober 2018.

Sholeh, M. (2007, April). Permintaan dan Penawaran Tenaga Kerja Serta Upah : Teori Serta Beberapa Potretnya di Indonesia. Jurnal Ekonomi dan Pendidikan, 4 No.1, 62-75.

Simanjuntak, P. J. (2005). Pengantar Ekonomi Sumber Daya Manusia. Jakarta: Fakultas Ekonomi UI.

Soleh, A. (2017). Masalah Ketenagakerjaan dan Pengangguran di Indonesia. Jurnal Ilmiah Cano Ekonomos, 6 No.2, 83-92.

Sukirno, S. (1996). Pengantar Teori Makroekonomi. Jakarta: Raja Grafindo Persada.

Sukirno, S. (2008). Teori Pengantar Makro Ekonomi. Jakarta: PT. Raja Grafindo Persada.

Sumarsono, S. (2009). Teori Kebijakan Publik Ekonomi Sumber Daya Manusia. Yogyakarta: Graha Ilmu.

Tjiptoherijanto, P., \& Soemitro, S. (1997). Sumber Daya Manusia dalam Pembangunan Nasional. Jakarta.

Wahyuni, Y. S. (2009). Analisis Pengangguran Tenaga Kerja Terdidik di Sumatera Barat 2007. http://repository.ui.ac.id diakses tanggal 13 Oktober 2018.

\section{Copyrights}

Copyright for this article is retained by the author(s), with first publication rights granted to the journal.

This is an open-access article distributed under the terms and conditions of the Creative Commons Attribution license (http://creativecommons.org/licenses/by/4.0/). 